\title{
Codon 129 polymorphism of prion protein gene in is not a risk factor for Alzheimer's disease
}

\author{
Polimorfismo do códon 129 do gene da proteína \\ priônica não é fator de risco para doença de Alzheimer \\ Jerusa Smid', Michele Christine Landemberger ${ }^{2}$, \\ Valéria Santoro Bahia', Vilma Regina Martins ${ }^{2}$, Ricardo Nitrini'
}

\begin{abstract}
Interaction of prion protein and amyloid-b oligomers has been demonstrated recently. Homozygosity at prion protein gene (PRNP) codon 129 is associated with higher risk for Creutzfeldt-Jakob disease. This polymorphism has been addressed as a possible risk factor in Alzheimer disease (AD). Objective: To describe the association between codon 129 polymorphisms and AD. Methods: We investigated the association of codon 129 polymorphism of PRNP in 99 AD patients and 111 controls, and the association between this polymorphism and cognitive performance. Other polymorphisms of PRNP and additive effect of apolipoprotein E gene (ApoE) were evaluated. Results: Codon 129 genotype distribution in $\mathrm{AD}$ 45.5\% methionine (MM), 42.2\% methionine valine (MV), 12.1\% valine (VV); and 39.6\% MM, 50.5\% MV, 9.9\% VV among controls ( $p>0.05$ ). There were no differences of cognitive performance concerning codon 129. Stratification according to ApoE genotype did not reveal difference between groups. Conclusion: Codon 129 polymorphism is not a risk factor for AD in Brazilian patients.
\end{abstract}

Key words: prion protein gene, Alzheimer's disease, polymorphism, codon 129, cognitive performance, apolipoprotein E gene.

\section{RESUMO}

A interação entre proteína priônica e oligômeros b-amiloide foi demonstrada recentemente. Homozigose no códon 129 do gene da proteína priônica (PRNP) é fator de risco para doença de Creutzfeldt-Jakob. Este polimorfismo foi estudado como possível fator de risco para doença de Alzheimer (DA). Objetivo: Estudar uma possivel associação entre o polimorfismo do códon 129 e DA. Métodos: Foram investigados 99 pacientes com DA e 111 controles em relação ao polimorfismo do códon 129 e sua associação com desempenho cognitivo. Foram pesquisados outros polimorfismos do PRNP e efeito aditivo do gene da apolipoproteína E (ApoE). Resultados: Distribuição no códon 129: 45,5\% metionina (MM), 42,2\% metionina valina (MV), 12,1\% valina (VV) nos pacientes com DA; e 39,6\% MM, 50,5\% MV, 9,9\% VV, nos controles ( $p>0.05$ ). Não houve diferença no desempenho cognitivo em relação ao códon 129. Estratificação pelo genótipo do ApoE não mostrou diferença entre grupos. Conclusão: Polimorfismo do códon 129 não é fator de risco para DA em pacientes brasileiros.

Palavras-Chave: gene da proteína priônica, doença de Alzheimer, polimorfismo, códon 129, desempenho cognitivo, gene da apolipoproteína E.

Human prion diseases are rare neurodegenerative disorders that occur sporadically, genetically determined or acquired. Sporadic Creutzfeldt-Jakob disease (CJD) is the commonest prion disease, with annual incidence of one case per one million. The genetic forms of prion diseases follow autosomal dominant inheritance and are associated with more than 50 mutations in the prion protein gene (PRNP) $)^{1,2}$. The codon 129 of PRNP is polymorphic, encoding either methionine
(M) or valine (V). Homozygosity at this codon is associated with a higher risk for sporadic CJD, and variant of CJD occurs exclusively in MM subjects ${ }^{3,4}$. The PRNP polymorphism at codon 129 has been investigated in different neurodegenerative diseases, including Alzheimer's disease (AD), Parkinson's disease and primary progressive aphasia. Its correlation with clinical parameters such as disease onset and cognitive performance is contradictory ${ }^{5-8}$.

\footnotetext{
Study carried out at Hospital das Clínicas, Universidade de São Paulo (USP); A.C. Camargo Hospital, São Paulo SP, Brazil.

${ }^{1}$ Cognitive and Behavioral Unit, Department of Neurology, School of Medicine, USP, São Paulo SP, Brazil;

${ }^{2}$ Molecular and Cellular Biology Group, International Center for Research, A.C. Camargo Cancer Center, São Paulo SP, Brazil.

Correspondence: Jerusa Smid; Rua Arruda Alvim 145 / apto 84;05410-020 São Paulo SP - Brasil; E-mail: jsmid@ig.com.br

Support: Fundação de Amparo à Pesquisa do Estado de São Paulo (FAPESP) Process nº 2009/01427-2, Howard Hughes Medical Institute, National Institute of Translational Neuroscience (INNT) - Conselho Nacional de Desenvolvimento Científico e Tecnológico/Ministério da Ciência e Tecnologia (CNPq/MCT) and Ludwig Institute for Cancer Research.

Conflict of interest: There is no conflict of interest to declare.
}

Received 05 December 2012; Received in final form 18 December 2012; Accepted 27 December 2012. 
$\mathrm{AD}$ is a common neurodegenerative disease and the most common cause of dementia in many countries. Some genetic risk factors have been studied in the sporadic cases of $\mathrm{AD}$, the most important one being the genotype of the apolipoprotein E gene (ApoE) $)^{9-11}$. The codon 129 polymorphism of PRNP was also addressed as a possible risk factor in $\mathrm{AD}$ patients. A few studies have shown that this polymorphism may be a risk factor for $\mathrm{AD}^{12-14}$. Others, however, failed to confirm such association, ${ }^{5,815-21}$. A meta-analysis concluded that codon 129 homozygosity of PRNP is a risk factor for $\mathrm{AD}$ in a Caucasian population $^{19}$. More recently, data from a pathology-confirmed $\mathrm{AD}$ population failed to support a role of codon 129 polymorphisms as a susceptibility factor for $\mathrm{AD}^{5}$.

$\mathrm{AD}$ and prion diseases are both pathogenically associated with the accumulation of misfolded protein fragments: b-amyloid protein and prion protein $\left(\mathrm{PrP}^{\mathrm{C}}\right)$, respectively ${ }^{22,23}$. Recently, the interaction of $\mathrm{PrP}^{\mathrm{C}}$ and amyloid-b oligomers has been demonstrated ${ }^{24,25}$. $\mathrm{PrP}^{\mathrm{C}}$ seems to be a high-affinity binding site for amyloid-b oligomers mediating neurotoxic$i^{24}$. Although controversies still exist, such findings brought new interest to the association of $\mathrm{AD}$ and $\mathrm{PrP}^{\mathrm{C}} 26$.

We investigated the association of codon 129 polymorphism of PRNP in AD patients and age-matched, cognitively healthy control group. We also evaluated the association between this polymorphism and the cognitive performance of $\mathrm{AD}$ and controls. Other polymorphisms of PRNP were also evaluated as well as the potential additive effect of ApoE upon codon 129 polymorphisms in $\mathrm{AD}$ and controls.

\section{METHODS}

Subjects were enrolled from the Cognitive and Behavioral Unit of the Neurologic Clinic of School of Medicine of Universidade de São Paulo (USP) and from a previous study ${ }^{11}$. The diagnosis of probable $\mathrm{AD}$ followed the recommendations of the joint working group of the National Institute of Neurologic and Communicative disorders and Stroke and the $\mathrm{AD}$ and Related Disorders Association (NINCDSADRDA). The control group comprised volunteers recruited from community and nonrelated caregivers of the $\mathrm{AD}$ patients. Individuals with neurological and psychiatric conditions and unstable medical diseases were excluded from the control group. The cognitive evaluation of controls was done with the Folstein Mini-Mental State Exam (MMSE) and semantic verbal fluency (VF) test.

Ninety-nine patients with probable AD and 111 healthy control subjects were enrolled for analysis. The demographic data of groups are shown in Table 1. Different subsamples were analyzed: early-onset $\mathrm{AD}$ (EOAD; <65 years) and lateonset $\mathrm{AD}$ ( $\mathrm{LOAD} ; \geq 65$ years). Control group subsamples were divided according to age at time of blood collection. The disease duration considered was the time between initial symptoms and the first cognitive evaluation.

The PRNP polymorphisms at codons 117, 129, 171 and octarepeat domain were analyzed using denaturing highperformance liquid chromatography. Technical details about this procedure as well as amplification reactions and DNA extraction have been previously described ${ }^{27}$.

The ApoE polymorphism $(\varepsilon 4+/ \varepsilon 4-)$ was evaluated in a subsample of $81 \mathrm{AD}$ patients and 94 controls. The ApoE analysis was performed as previously described by Bahia et al. ${ }^{11}$.

To compare frequencies of genotypes and alleles, we used Pearson $\chi^{2}$ test or Fisher's exact test when sample size was small. Sex distribution was compared between patients and controls using Pearson $\chi^{2}$ test. Age and schooling distribution were compared using MannWhitney test. Kruskall-Wallis test was used to compare median between three or more groups. Logistic regression models were used to control for potential confounding effect of sex, age and schooling. Odds ratio (OR) and 95\% confidence intervals (CI) were calculated from the logistic regression models. Statistical analyses were done using Stata 11.0 program.

Table 1. Demographic data of Alzheimer's disease and control groups.

\begin{tabular}{|c|c|c|c|}
\hline & Alzheimer's disease & Controls & $\mathrm{p}$-value \\
\hline$n$ & 99 & 111 & \\
\hline Women & $66(66.7 \%)$ & $76(68.5 \%)$ & 0.781 \\
\hline Mean age at disease onset in years (SD) & $72.2(9.1)$ & & \\
\hline Mean age at blood collection in years (SD) & & $71.4(8.2)$ & \\
\hline Age median in years (range) & $74(50-90)$ & $71(53-90)$ & $0.236 *$ \\
\hline Mean time of disease course (SD) & $30.5(20.1)^{+}$ & & \\
\hline Age (years) & & & 0.536 \\
\hline$<65$ & $21(21.2)$ & $28(25.2)$ & \\
\hline 65 a 74 & $35(35.4)$ & $43(38.7)$ & \\
\hline$\geq 75$ & $43(43.4)$ & $40(36.1)$ & \\
\hline Schooling & & & $0.060 *$ \\
\hline Median (range) & $4.0(0-17)^{\#}$ & $6.5(0-16)^{+}$ & \\
\hline Mean (SD) & $6.3(5.2)^{\#}$ & $7.1(4.1)^{\dagger}$ & \\
\hline
\end{tabular}

*Mann-Whitney test; ${ }^{*} n=91 ;{ }^{\dagger} n=66$. SD: standard deviation. 


\section{Ethics}

This study was approved by the Ethics Committee for analysis of research projects (CAPPesq) of Hospital das Clínicas, School of Medicine, USP. Subjects signed the informed consent form. When patient had the diagnosis of moderate or severe dementia, the written informed consent was given by a close relative. The study was conducted in compliance with the Declaration of Helsinki.

\section{RESULTS}

The genotype distribution of codon 129 polymorphisms in the AD group was $45.5 \% \mathrm{MM}, 42.2 \% \mathrm{MV}$, and $12.1 \% \mathrm{VV}$; and 39.6\% MM, 50.5\% MV, and 9.9\% VV among controls. The genotype distributions were not statistically different between groups. Subgroup analysis according to age at onset revealed no difference of genotype distribution between patients with EOAD and LOAD and the respective control groups. The analysis of $\mathrm{M}$ and $\mathrm{V}$ allele frequency, as well as homozygosity and heterozygosity distribution did not significantly differ between $\mathrm{AD}$ and control groups. These results are displayed in Tab. 2. The genotype distributions were in Hardy-Weinberg equilibrium.

The genotype distribution at codons 117, 171 and octapeptide domain were not different between $\mathrm{AD}$ patients and controls (data not shown).

Concerning the cognitive evaluation, MMSE scores were significantly higher in $\mathrm{AD}$ patients with $\mathrm{VV}$ polymorphism and lower in patients with MM genotype (Table 3). The median time of disease was significantly shorter in VV patients and longer in MM patients. Logistic regression model did not confirm the association of MMSE performance and codon 129 polymorphism in $\mathrm{AD}$ group. There were no differences at $\mathrm{VF}$ test performance of $\mathrm{AD}$ patients as well as at MMSE and VF test performance of controls concerning the codon 129.

The stratification according to the ApoE genotype did not reveal any difference in the frequency of codon 129 polymorphism between $\mathrm{AD}$ and control groups (Table 2).

\section{DISCUSSION}

The codon 129 polymorphism of PRNP has been associated with $\mathrm{AD}$ and cognitive performance in the elderly population ${ }^{19,28}$. Although reports show contradictory results, this polymorphism has been associated with different phenotypes in prion diseases and other neurodegenerative diseases $^{3-8}$.

The homozygosity for $\mathrm{V}$ was associated with higher risk of cognitive impairment in two large populational studies ${ }^{28,29}$. On the other hand, the homozygosity for $\mathrm{M}$ was also associated with lower scores on cognitive tests in cognitive normal population ${ }^{30}$.

The evaluation of $\mathrm{AD}$ patients in populations worldwide shows divergent results. In an Italian sample, despite no difference between the frequency of codon 129 polymorphisms in $\mathrm{AD}$ patients, the presence of one $\mathrm{V}$ allele was related to phenotypic characteristics: earlier disease onset and more aggressive disease ${ }^{16}$. In another Italian report, only VV genotype was associated with a faster rate of cognitive decline ${ }^{19}$.

Table 2. Genotype, alleles, and homozygosity frequencies in cases and controls.

\begin{tabular}{|c|c|c|c|c|c|c|c|c|c|c|c|}
\hline & \multirow{2}{*}{$\mathrm{n}$} & \multicolumn{4}{|c|}{ Codon $129(\%)$} & \multicolumn{3}{|c|}{ Allele frequency } & \multicolumn{3}{|c|}{ Homozygosity (\%) } \\
\hline & & $\mathrm{M} / \mathrm{M}$ & $\mathrm{M} / \mathrm{V}$ & $\mathrm{V} / \mathrm{V}$ & $p$-value & M & V & $\mathrm{p}$-value & Yes & No & $\mathrm{p}$-value \\
\hline \multicolumn{12}{|l|}{ Group } \\
\hline Probable AD & 99 & $45(45.5)$ & 42(42.4) & $12(12.1)$ & 0.50 & 0.67 & 0.33 & 0.70 & $57(57.6)$ & $42(42.4)$ & 0.25 \\
\hline Controls & 111 & $44(39.6)$ & $56(50.5)$ & $11(9.9)$ & & 0.65 & 0.35 & & & & \\
\hline \multicolumn{12}{|l|}{$<65$ years } \\
\hline EOAD & 21 & $12(57.1)$ & $8(38.1)$ & $1(4.8)$ & 0.86 & 0.76 & 0.24 & 0.60 & $13(61.9)$ & $8(38.1)$ & 0.74 \\
\hline Controls & 28 & $14(50.0)$ & $12(42.9)$ & $2(7.1)$ & & 0.71 & 0.29 & & $16(57.1)$ & $12(42.9)$ & \\
\hline \multicolumn{12}{|l|}{$\geq 65$ years } \\
\hline LOAD & 78 & $33(42.3)$ & $34(43.6)$ & $11(14.1)$ & 0.48 & 0.64 & 0.36 & 0.79 & $44(56.4)$ & $34(43.6)$ & 0.23 \\
\hline Controls & 83 & $30(36.1)$ & $44(53.0)$ & $9(10.8)$ & & 0.63 & 0.37 & & $39(47.0)$ & $44(53.0)$ & \\
\hline \multicolumn{12}{|l|}{$A D$} \\
\hline EOAD & 21 & $12(57.1)$ & $8(38.1)$ & $1(4.8)$ & 0.35 & 0.76 & 0.24 & 0.14 & $13(61.9)$ & $8(38.1)$ & 0.65 \\
\hline LOAD & 78 & $33(42.3)$ & $34(43.6)$ & $11(14.1)$ & & 0.64 & 0.36 & & $44(56.4)$ & 34 (43.6) & \\
\hline \multicolumn{12}{|l|}{ ApoE $\varepsilon 4+$} \\
\hline$A D$ & 41 & 19 (46.3) & 19 (46.3) & $3(7.3)$ & 0.81 & 0.70 & 0.30 & 0.78 & $22(53.7)$ & 19 (46.3) & 0.57 \\
\hline Control & 17 & $6(35.3)$ & $10(58.9)$ & $1(5.9)$ & & 0.65 & 0.35 & & $7(41.2)$ & $10(58.8)$ & \\
\hline \multicolumn{12}{|l|}{ ApoE $\varepsilon 4-$} \\
\hline$A D$ & 40 & $17(42.5)$ & $17(42.5)$ & $6(15)$ & 0.57 & 0.64 & 0.36 & 0.89 & $23(57.5)$ & $17(42.5)$ & 0.44 \\
\hline Control & 77 & $29(37.7)$ & $40(51.9)$ & $8(10.4)$ & & 0.64 & 0.36 & & $37(48.1)$ & $40(51.9)$ & \\
\hline
\end{tabular}

AD: Alzheimer's disease; EOAD: early-onset AD; LOAD: late-onset AD; M: methionine; V: valine; ApoE: apolioprotein E gene. 
Table 3. Cognitive performance in Alzheimer's disease patients according to prion protein gene codon 129

\begin{tabular}{|c|c|c|c|c|}
\hline & $\mathrm{MM}$ & MV & VV & $\mathrm{p}$-value \\
\hline MMSE** & $n=44$ & $n=36$ & $n=12$ & $0.006^{*}$ \\
\hline Mean (SD) & $14.8(6.1)$ & $18.1(4.9)$ & $19.5(5.7)$ & \\
\hline Median (Range) & $16.5(0-24)$ & $19.0(3-25)$ & $21.0(6-26)$ & \\
\hline VF & $n=33$ & $n=27$ & $n=10$ & 0.077 \\
\hline Mean (SD) & $7.0(3.7)$ & $8.6(3.9)$ & $9.9(4.4)$ & \\
\hline Median (Range) & $7.0(0-15)$ & $8.0(0-18)$ & $11.0(2-15)$ & \\
\hline Disease duration (months) ${ }^{\star \star \star}$ & $n=44$ & $n=35$ & $n=12$ & $0.022 *$ \\
\hline Mean (SD) & $35.1(20.4)$ & $25.4(18.7)$ & $28.5(20.3)$ & \\
\hline Median (Range) & $33.0(6-96)$ & $24.0(6-72)$ & $21.0(12-72)$ & \\
\hline Age (years) & $n=44$ & $n=36$ & $n=12$ & $0.393 *$ \\
\hline Mean (SD) & $71.2(9.5)$ & $73.9(9.3)$ & $73.0(8.7)$ & \\
\hline Median (Range) & $73.5(50-90)$ & $75.5(52-87)$ & $73.5(51-88)$ & \\
\hline Schooling (years) & $n=44$ & $n=35$ & $n=12$ & $0.922 *$ \\
\hline Mean (SD) & $6.6(5.7)$ & $6.2(5.2)$ & $4.9(3.3)$ & \\
\hline Median (Range) & $4(0-17)$ & $4(0-17)$ & $4(2-15)$ & \\
\hline Gender & $n=44$ & $n=36$ & $n=12$ & 0.369 \\
\hline Female - Mean (SD) & $29(65.9)$ & $22(61.1)$ & 10 (83.3) & \\
\hline Male - Mean (SD) & $15(34.1)$ & $14(38.9)$ & $2(16.7)$ & \\
\hline
\end{tabular}

*Kruskal Wallis. M: methionine; V: valine; SD: standard deviation; MM versus MV p<0.001; MV versus VV p<0.001; MM versus VV p<0.001;

In a few European studies, codon 129 polymorphisms have been demonstrated to confer higher risk to $\mathrm{AD}$. In a Dutch report, EOAD was more frequent in patients with family history of $\mathrm{AD}$ and codon 129 homozygosity, particularly $\mathrm{VV}^{17}$. The increased risk for EOAD was also demonstrated in MM patients in Germany ${ }^{13}$. In a Polish study, MM genotype was found to be a genetic risk factor only in $\mathrm{LOAD}^{14}$.

In Asian countries, all reported studies failed to demonstrate any association between the PRNP polymorphism at codon 129 and $\mathrm{AD}^{18,20,31}$. Of note, $\mathrm{VV}$ genotype is very rare in the Asian population ${ }^{18,31}$.

Our results are in line with most of the studies reported to date. We failed to find any association between the codon 129 polymorphisms of PRNP and $\mathrm{AD}$, even when patients were divided in EOAD and LOAD. The frequency of the genotypes in the studied groups was similar to that previously described in a Brazilian population of blood donors: $45.6 \% \mathrm{MM}, 48.2 \%$ $\mathrm{MV}$, and $6.2 \% \mathrm{VV}^{32}$.

Our results are also in agreement with the unique neuropathologically supported data that refutes the association between codon 129 polymorphism and $\mathrm{AD}^{8}$. The patients described here presenting VV genotype scored better at MMSE, which is contradictory to other data showing that codon 129 homozygosity is associated with lower cognitive performance ${ }^{28-30}$. This result could be explained by the shorter period of disease of $\mathrm{VV}$ patients and not by the codon 129 polymorphism. This is particularly reinforced by the logistic regression analysis that refuted the association between MMSE performance and different genotypes at codon 129 .

In opposition to some studies, which showed interaction between ApoE and PRNP, our data did not reveal differences in codon 129 genotypes according to the ApoE status ${ }^{13-21}$.

This study of PRNP in patients with $\mathrm{AD}$ in the Brazilian population has, as its main limitation, the small sample. Additional studies would be necessary to confirm these negative results regarding the relationship between $\mathrm{AD}$ and the polymorphism at codon 129 of PRNP.

\section{ACKNOWLEDGMENTS}

Authors thank Dr. Marcus Vinícius de Nigro Corpa for linguistic editing.

\section{References}

1. Glatzel M, Ott PM, Linder T, et al. Human prion diseases: epidemiology and integrated risk assessment. Lancet Neurol 2003;2:757-763.

2. Brandel JP, Delasnerie-Lauprêtre N, Laplanche JL, Hauw JJ, Alpérovitch A. Diagnosis of Creutzfeldt-Jakob disease: effect of clinical criteria on incidence estimates. Neurology 2000;54:1095-1099.
3. Parchi P, Castellani R, Capellari S, et al. Molecular basis of phenotypic variability in sporadic Creutzfeldt-Jakob disease. Ann Neurol 1996;39:767-778.

4. Bishop MT, Pennington C, Heath CA, Will RG, Knight RSG. PRNP variation in UK sporadic and variant Creutzfeldt-Jakob disease highlights genetic risk factors and a novel non-synonymous polymorphism. BMC Med Genet 2009;10:146. 
5. Poleggi A, Bizzarro A, Acciarri A, et al. Codon 129 polymorphism of prion protein gene in sporadic Alzheimer's disease. Eur J Neurol 2008;15:173-178.

6. Gossrau G, Herting B, Möckel S, et al. Analysis of the polymorphic prion protein gene codon 129 in idiopathic Parkinson's disease. J Neural Transm 2006;113:331-337.

7. Scholz SW, Xiromerisiou G, Fung HC, et al. The human prion gene M129V polymorphism is not associated with idiopathic Parkinson's disease in three distinct populations. Neurosci Lett 2006;395:227-229.

8. LiX, Rowland LP, Mitsumoto H, et al. Prion protein codon 129 genotype prevalence is altered in primary progressive aphasia. Ann Neurol 2005;58:858-864.

9. Herrera Jr. E, Caramelli P, Silveira ASB, Nitrini R. Epidemiologic survey of dementia in a community-dwelling Brazilian population. Alzheimer Dis Assoc Disord 2002;16:103-108.

10. Strittmatter WJ, Saunders AM, Schmechel D, et al. Apolipoprotein E: high-avidity binding to b-amyloid and increased frequency of type 4 allele in late-onset familial Alzheimer disease. Proc Natl Acad Sci USA 1993; 90:1977-1981.

11. Bahia VS, Kok F, Marie SN, Shinjo SO, Caramelli P, Nitrini R. Polymorphisms of APOE and LRP genes in Brazilian individuals with Alzheimer disease. Alzheimer Dis Assoc Disord 2008;22:61-65.

12. Golanska E, Hulas-Bigoszewska K, Rutkiewicz E, et al. Polymorphisms within the prion (PrP) and prion-like protein (Doppel) genes in AD. Neurology 2004;62:313-315.

13. Riemenschneider M, Klopp N, Xiang W, et al. Prion protein codon 129 polymorphism and risk of Alzheimer disease. Neurology 2004;63:364-366.

14. Gacia M,Safranow K, Styczyñska M, et al. Prion protein gene M129V allele is a risk factor for Alzheimer's disease.J Neural Transm 2006;113:1747-1751.

15. Combarros O, Sánchez-Guerra M, Llorca J, et al. Polymorphism at codon 129 of the prion protein gene is not associated with sporadic AD. Neurology 2000;55:593-595.

16. Casadei VM, Ferri C, Calabrese E, et al. Prion protein gene polymorphism and Alzheimer's disease: one modulatory trait or cognitive decline? J Neurol Neurosurg Psychiatry 2001;71:278-283.

17. Dermaut B, Croes EA, Rademakers R, et al. PRNP Val129 homozygosity increases risk for early-onset Alzheimer's disease. Ann Neurol 2003;53:409-412.

18. Onkubo T, Sakasegawa Y, Asada T, Kinoshita T, Goto Y, Kimura H, et al. Absence of association between codon 129/219 polymorphism of the prion protein gene and Alzheimer's disease in Japan. Ann Neurol 2003;54:553-554.
19. Del Bo R, Scarlato M, Ghezzi S, et al. Is M129V of PRNP gene associated with Alzheimer disease? A case-control study and metaanalysis. Neurobiol Aging 2006;27:770-775.

20. Jeong B-H, Lee K-H, Jeong Y-E, et al. Polymorphisms at codons 129 and 219 of the prion protein gene (PRNP) are not associated with sporadic Alzheimer's disease in the Korean population. Eur J Neurol 2007;14:621-626.

21. Calero O, Bullido MJ, Clarimón J, et al. Genetic cross-interaction between APOE and PRNP in sporadic Alzheimer's and CreutzfeldtJakob diseases. PLoS One 2011;6:22090.

22. Prusiner SB. Prions. Proc Natl Acad Sci USA 1998;95:13363-11383.

23. Querfurth HW, LaFerla FM. Alzheimer's disease. N Engl J Med 2010;362:329-344

24. Laurén J, Gimbel DA, Nygaard HB, Gilbert JW, Strittmatter SM. Cellular prion protein mediates impairment of synaptic plasticity by amyloid-b oligomers. Nature 2009;457:1128-1132.

25. Gimbel DA, Nygaard HB, Coffey EE, et al. Memory impairment in transgenic Alzheimer mice requires cellular prion protein. J Neurosc 2010;30:6367-6374.

26. Calella AM, Farinelli M, Nuvolone M, et al. Prion protein and Abrelated synaptic toxicity impairment. EMBO Mol Med 2010;2: 306-314.

27. Castro RM, Landemberger MC, Walz R, et al. High capacity and low cost detection of prion protein gene variant alleles by denaturing HPLC. J Neurosci Methods 2004;139:263-269.

28. Berr C, Richard F, Dufouil C, et al. Polymorphism of the prion protein is associated with cognitive impairment in the elderly. The EVA study. Neurology 1998;51:734-737.

29. Croes EA, Dermaut B, Houwing-Duistermaat JJ, et al. Early cognitive decline is associated with prion protein codon 129 polymorphism. Ann Neurol 2003;54:275-276.

30. Rujescu D, Hartmann AM, Gonnermann C, Möller H-J, Giegling I. M129V variation in the prion protein may influence cognitive performance. Mol Psychiatry 2003;8:937-941.

31. Jeong $\mathrm{BH}, \mathrm{Nam} \mathrm{JH}$, Lee $\mathrm{YJ}$, et al. Polymorphisms of the prion protein gene (PRNP) in a Korean population. J Hum Genet 2004;49: 319-324.

32. de Paula EV, Addas-Carvalho M, Costa DSP, Saad STO, Gilli SCO. Genotype frequencies at codon 129 of the prion protein gene in Brazil: implications in susceptibility to variant Creutzfeldt-Jakob disease compared to European and Asian populations. Eur J Epidemio 2005;20:593-595. 